\title{
Internet-based Land Valuation System Powered by a GIS of 1:10,000 Soil Maps
}

\author{
${ }^{1}$ T. TÓTH, ${ }^{1}$ T. NÉMETH, ${ }^{2}$ T. FÁBIÁN, ${ }^{3}$ T. HERMANN, ${ }^{1}$ E. HORVÁTH, \\ ${ }^{4}$ Z. PATOCSKAI ${ }^{3}$ F. SPEISER, ${ }^{5}$ SZ.VINOGRADOV and ${ }^{1,6}$ G. TÓTH \\ ${ }^{1}$ Research Institute for Soil Science and Agricultural Chemistry (RISSAC) of the \\ Hungarian Academy of Sciences, Budapest; ${ }^{2}$ Kaposvár University, Kaposvár; \\ ${ }^{3}$ Veszprém University, Veszprém; ${ }^{4}$ University of Western Hungary, Sopron; \\ ${ }^{5}$ Szent István University, Gödöllő (Hungary) and ${ }^{6}$ EC JRC Institute for Environment \\ and Sustainability, Ispra (Italy)
}

\section{Introduction}

The improper use of land resources and the suboptimal economic considerations of profitability of agronomy have lead to unsustainable production. The land's physical as well as economic conditions determine the optimal use of each field. Land valuation serves with information that can be used in several stages of land management (BURROUGH, 1987), including routine decisions during the growing season, and also provides a parameter for official use, such as land consolidation, land taxation, land exchange and a proxy for land purchase as well.

The problems arising from the use of the only legally established Hungarian land valuation index (that is the land value index used for state taxation, land exchange, appropriation, subsidy calculation etc.) the Gold Crown ("Aranykorona", or AK) value are numerous. After more than one hundred and thirty years" use, there is need for an improved index, which not only substitutes the AK value, but provides the basis of a complex set of land management operations for securing sustainable production.

Although there has been a very promising attempt for replacing the AK value, such as the "Hundred-point land valuation system" presented by FóRIzs et al. (1971), it has not been successful.

At the current level of digital techniques, it is possible to build systems that are capable of providing online instantaneous calculations of complex indicator values, as shown by LEMMENS and KURM (2000) for the valuation of Estonian lands.

Therefore, after a project (D-e-Meter) intending to develop an algorithm for a scientifically based parameter of soil quality ("Land Quality" according to the definition of ROSSITER, 1996) (GAÁL et al., 2003) a new project has been initiated for

Correspondence to: TIBOR TÓTH, Research Institute for Soil Science and Agricultural Chemistry of the Hungarian Academy of Sciences, H-1022 Budapest, Herman Ottó út 15. Hungary.E-mail: tibor@rissac.hu 
developing a contemporary method for the assessment of land value. The bases of the new method are the 1:10,000 scale genetic soil type maps and soil attribute information, which are available for $60 \%$ of the croplands in Hungary.

The objective of the current research is to use the collected information for each cadastral unit of production, the "field" (croplands, forests, grasslands) by a multifunctional approach to assist the farmers in decision making processes, and to provide a specific standard method for the evaluation of the land, too. This is done with a Geographical Information System (GIS) updated regularly with data on soil properties, economic factors of production, data of agronomic field records. The internet-based algorithm provides input/output possibility to/from the system for farmers, consultants, authorities, bankers, local administrators and politicians as well.

\section{Materials and Methods}

In the frame of the previous "D-e-Meter" project an internet-based soil quality index was developed, which is based on the processing of three major databases:

1. The statistical interpretation of the "AIIR" soil and yield database compiled between 1985 and 1989 from the agronomic field records kept by the farms. These data were collected from 60,000 fields, covering 4 million hectares yearly.

The database contains information on

- basic data for identification (location, size, slope, exposure, meteorological region, "AK" value etc.);

- soil analytical data ( $\mathrm{pH}$, texture, organic matter, $\mathrm{N}, \mathrm{P}, \mathrm{K}$ concentration);

- agronomic field records (crops, crop rotations, yields, application of fertilizers and manure).

2. Statistical processing of data from the long-term field trial network (MAGYAR et al., 2002). Nine field study sites provided data from long-term field experiments running with the same standard fertilization rates, but representing nine different agroecological regions of Hungary (BIRCSÁK \& NÉMETH, 2002).

3. Data collected in pilot study sites of farms on the effects of cultivation and crop rotation on yields (GAÁL et al., 2003).

The five steps in the calculation of D-e-Meter points were as follows:

Step 1. Base point calculated for: a) each genetic soil subtype of the Hungarian national soil classification scheme (SZABOLCS, 1966) specified for b) crop type, c) water regime of the soil, d) management intensity level (extensive or intensive), for each e) meteorological region of the grown crop, for each f) meteorological type of the year (dry, average, good in terms of the crop yield).

Step 2. Correction with the effect of different ranges of soil parameters (soil texture category, soil organic matter category, soil $\mathrm{pH}$ category, soil parent material).

Step 3. Correction with the effect of different levels of nutrient availability.

Step 4. Correction with the effect of relief and exposure.

Step 5. Correction with the effect of forecrops. 


\section{Results and Discussion}

In the frame of the present project "Land quality, land value and sustainable land use in Hungary (as an EU Member State)" indices similar to the D-e-Meter soil quality index of cropland are being developed, but in this case they will be formulated for forests and grasslands as well. The project's main aim is the development of a final economic index, "Land value", which incorporates not only the land quality indices, but also the economic value of the land.

A tool for calculations and visualization is the Geographical Information System (GIS) of soil resources linked to a database (VASS et al., 2003). The database provisional unit of the internet-based system contains continuously updated data of each field on soil cultivation, soil amelioration, events resulting in yield loss (drought, wild animals etc.), fertilization, plant protection. In the GIS the field is identified at the level of cadastral unit of land registry, genetic soil map unit and farmer (owner or renter) as well.

Important steps of the new project were the compilation of the schemes for the calculation of soil quality indices for forest soils (Fig. 1) and grassland soils (Fig. 2 ). Both indices are based on the productivity of the land and respect the traditions of forestry and animal husbandry, respectively. Since the "Production capacity of forest soil" is defined as the harvestable amount of timber for a given forest tree species (such as beech - Fagus silvatica) there is a close analogy with the principle of D-e-Meter soil quality, which is also calculated for each crop. In the case of forestry a favourable condition is the existence of a large database on yearly forest tree stock growth with detailed soil description (BIDLO et al., 2003). The database can be used in the same way as the AIIR data, now for establishing the relationship between soil subtypes and the harvestable amount of timber.

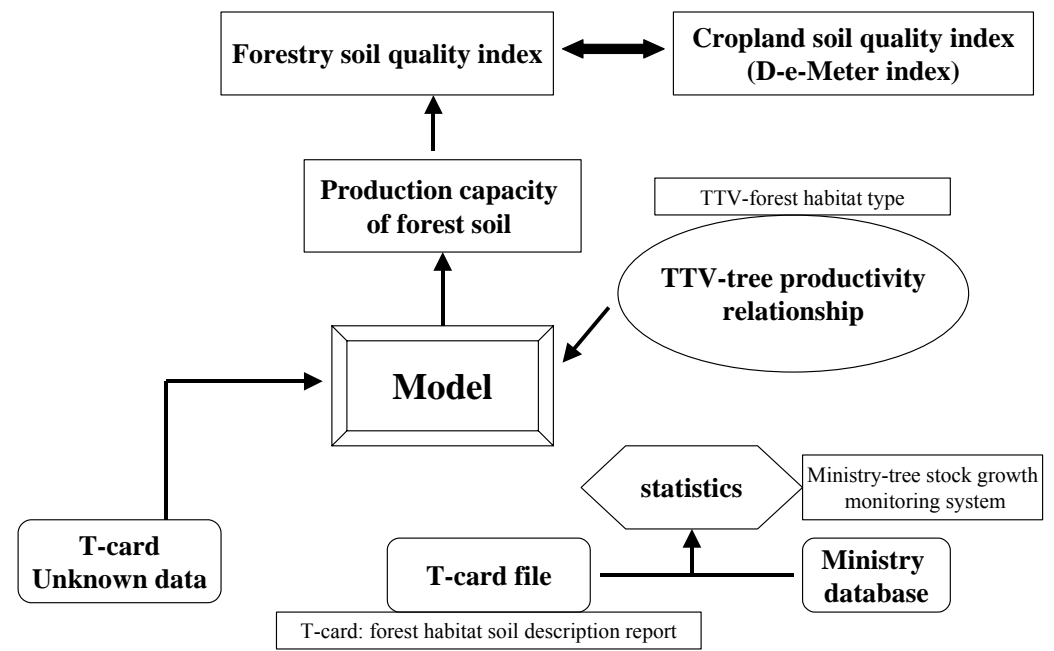

Fig. 1

Calculation scheme of soil quality for forest soils 
Less data are available on grasslands due to their present limited economic importance. In this case the most important production indicator is the carrying capacity (DÉR et al., 2003), which is expressed in terms of large grazing animals, completely analogous with the other two soil quality indices. A difficulty arising with grasslands is caused by the existence of a wide range of natural, semi-natural and seeded grasslands, which complicates the calculation of a soil quality index (Fig. 2). It is fortunate that the expected grass (hay) yield of the existing grasslands (catego-

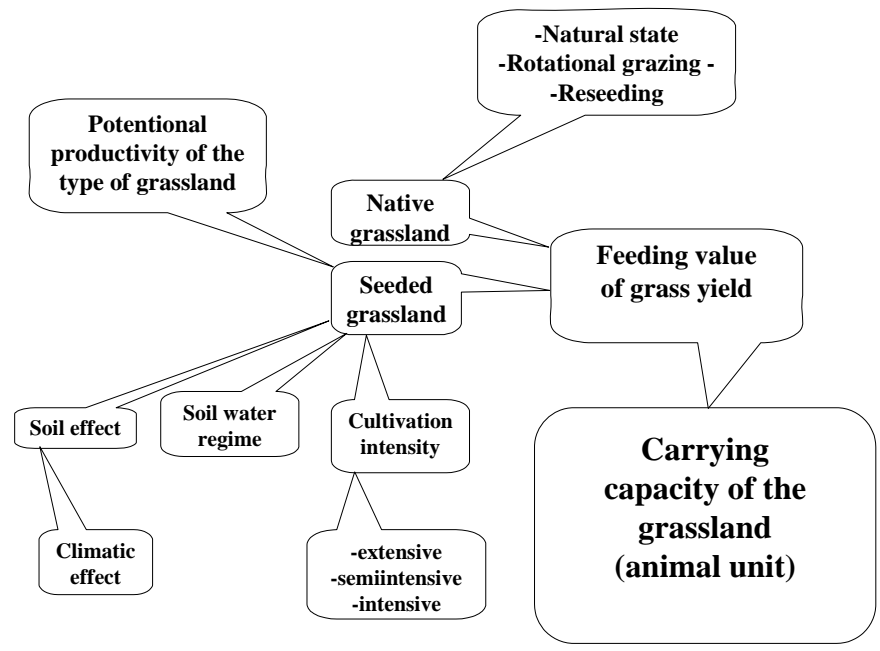

Fig. 2

Calculation scheme of soil quality index for grassland soils

rized in terms of dominant grass species, such as Festuca pratensis) of Hungary has already been assessed by VINCZEFFY (1993).

Calculation of the land value index is based on the D-e-Meter soil quality index of the individual field (Fig. 3). Each factor can either be provided as an input data from a database, or readily calculated based on available GIS data. The range of producible crops is calculable from the average yields on a given soil subtype. Objects limiting crop cultivation are inferable from the topographic maps in the same way as the distance to roads and markets. Exposure to temporary waterlogging after snowmelt and rains can be inferred with an automatic algorithm based on the Digital Elevation Model.

Parallel to the presented methodological researches, the development of databases is going on with two objectives: to provide detailed data for modelling relationships between land characteristics and yields of croplands, forests and grasslands; and to create working databases for testing the land valuation system (working combination of hardware and software). A separate project on the regional application of D-e-Meter soil quality assessment system (AKF) - $2004-3.1 .1$ ) helps in recruiting farmers willing to apply the system and supports enhancing its functionality in Zala county (Hungary). 


\begin{tabular}{|c|c|c|c|c|c|c|c|}
\hline \multicolumn{2}{|c|}{$\begin{array}{l}\text { Cropland soil quality index } \\
\text { (D- } e \text {-Meter index) }\end{array}$} & & & & & & \\
\hline \multicolumn{8}{|c|}{$\downarrow$} \\
\hline \multicolumn{2}{|c|}{ Range of producible crops } & $\rightarrow$ & \multicolumn{2}{|c|}{ Externals } & & & \\
\hline \multicolumn{2}{|c|}{$\downarrow$} & \multirow{3}{*}{$+/-$} & \multicolumn{2}{|c|}{$\downarrow$} & \multirow{3}{*}{$=$} & & \\
\hline \multicolumn{2}{|c|}{$\begin{array}{c}\text { Production equivalent } \\
\text { Gross margin (based on the } \\
\text { produced crops) }\end{array}$} & & $\begin{array}{r}\text { Recogniz } \\
\text { (benefits fo }\end{array}$ & $\begin{array}{l}\text { externals } \\
\text { he society) }\end{array}$ & & \multicolumn{2}{|c|}{$\begin{array}{c}\text { Total standard gross } \\
\text { margin } \\
\text { (EURO 0S/05/2004) }\end{array}$} \\
\hline \multicolumn{2}{|c|}{$\uparrow$} & & \multicolumn{2}{|c|}{$\uparrow$} & & & \\
\hline \multicolumn{8}{|c|}{ Correction factors } \\
\hline $\begin{array}{c}\text { Elasticity } \\
\text { coefficients }\end{array}$ & $\begin{array}{l}\text { Objects limiting } \\
\text { crop cultivation }\end{array}$ & \multicolumn{2}{|c|}{ Exposure to waterlogging } & \multicolumn{4}{|c|}{ Other factors } \\
\hline a & b & $\mathbf{c}_{1}$ & $\mathbf{c}_{2}$ & 1 & & & 3 \\
\hline $\begin{array}{l}\text { Based on the } \\
\text { number of } \\
\text { producible } \\
\text { crops }\end{array}$ & $\begin{array}{c}\text { Electric wire, } \\
\text { etc. }\end{array}$ & $\begin{array}{c}\text { For 1-4 } \\
\text { weeks }\end{array}$ & $\begin{array}{l}\text { Longer than } \\
4 \text { weeks }\end{array}$ & $\begin{array}{c}\text { Location } \\
\text { (road } \\
\text { conditions) }\end{array}$ & $\begin{array}{r}\text { Ma } \\
\text { dist }\end{array}$ & $\begin{array}{l}\text { ket } \\
\text { nces }\end{array}$ & $\begin{array}{c}\text { Other } \\
\text { economic } \\
\text { factors }\end{array}$ \\
\hline B (bad) & B & B & B & B & & & B \\
\hline M (medium) & M & M & M & $\mathbf{M}$ & & & M \\
\hline G (good) & G & G & G & G & & & G \\
\hline
\end{tabular}

Fig. 3

Calculation of the land value index

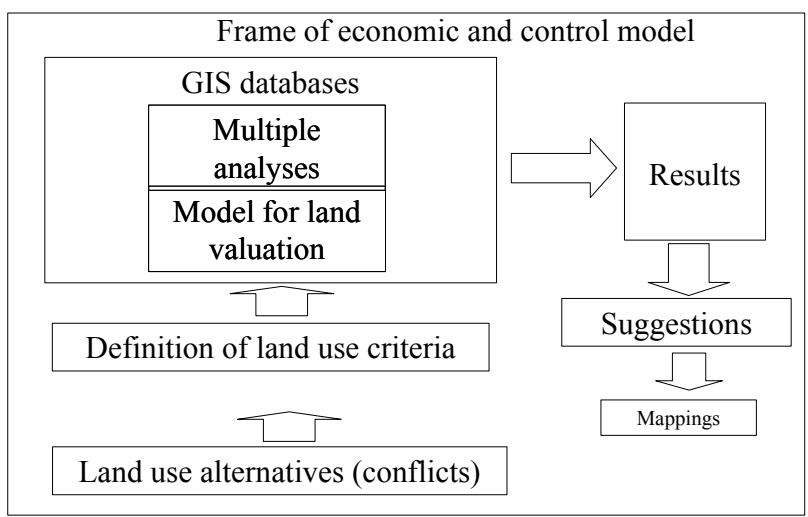

Fig. 4

The method of testing alternative land use scenarios 
A. Winter wheat

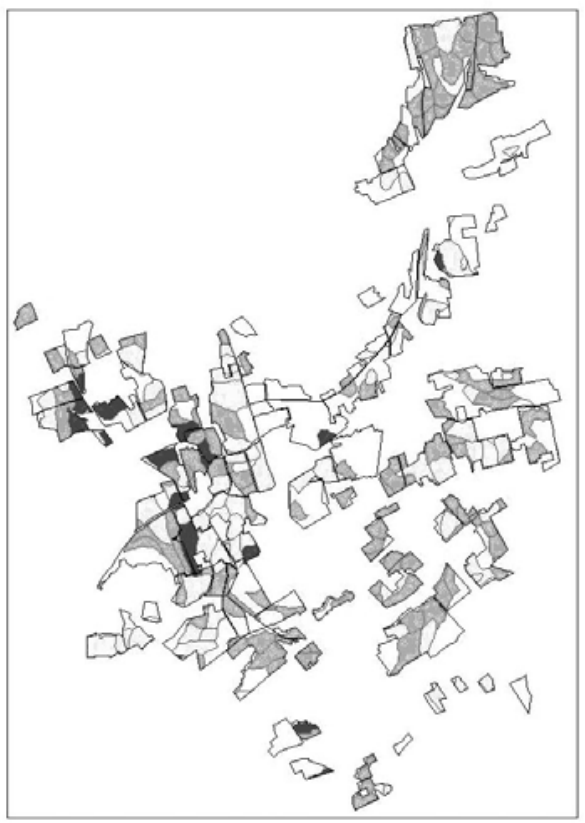

B. Maize

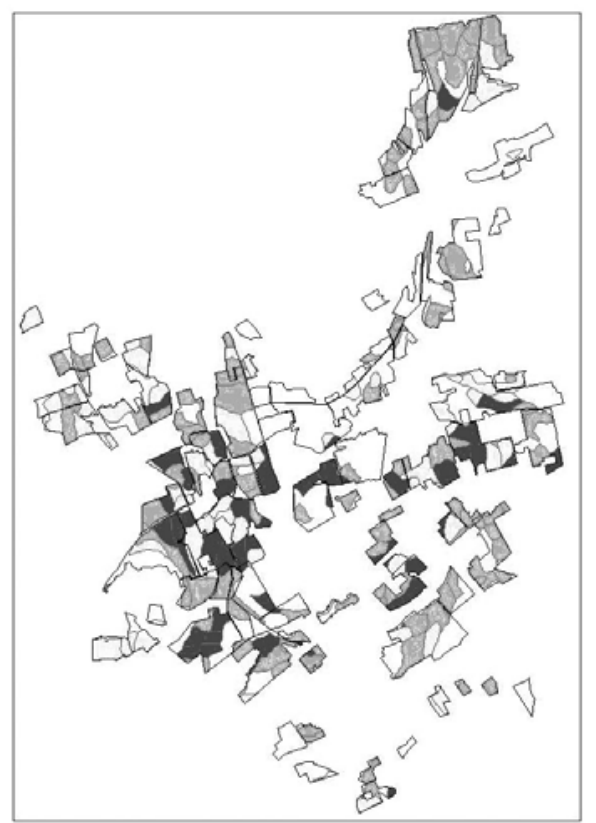

\section{Sunflower}

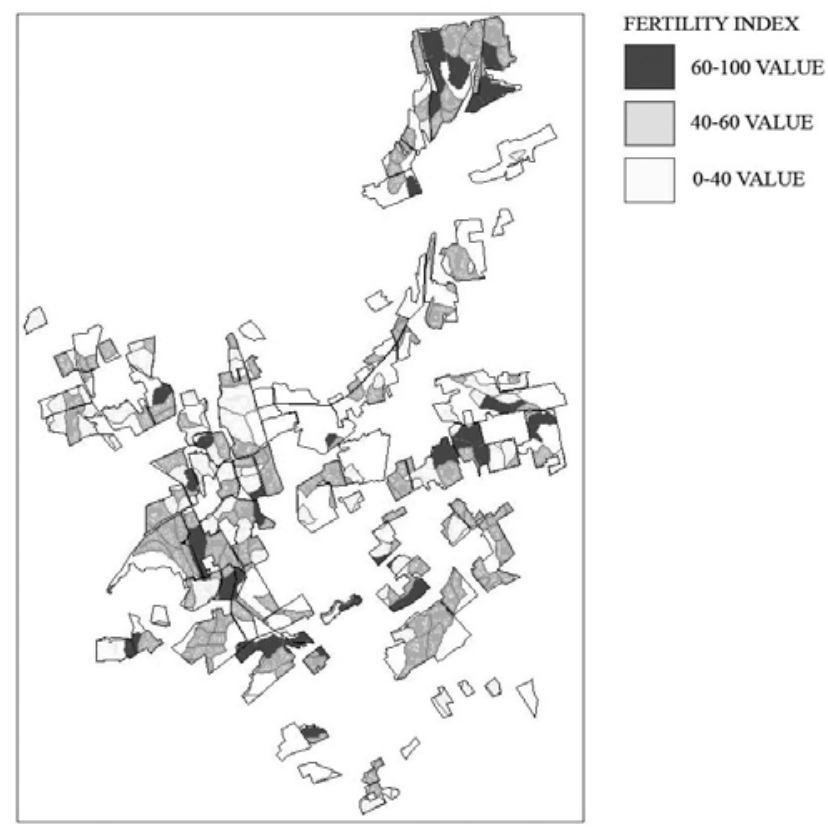

Fig. 5

The soil quality (fertility) index of croplands in a pilot study site (Kővágóörs, Hungary) according to different crops (winter wheat, maize and sunflower) 
As one of the final products of the system, a comparison of possible land use alternatives will be made (Fig. 4). This is expected to result in suggestions provided in the form of maps on the optimal sustainable use of land resources under the contemporary conditions of agronomic production in Hungary. The testing of alternative land use scenarios will serve with a direct guideline for optimal land use, incorporating knowledge on major land use types, such as croplands (ca $52 \%$ of the total territory of the country), forests (ca 20\%) and grasslands (ca 11\%). As the territory of settlements, roads makes up some $10 \%$ of land, not more than $7 \%$ of land (such as reed land, orchards, vineyards etc.) will remain uncovered by the land valuation system. Land use alternatives (changing from cropland to forest etc.) and the selection of different crops will also be made possible with the system. The final evaluation of specific land uses can be realized at all administrative levels, ranging from cadastral unit up to national level.

A preliminary testing showed how the system will be utilizable for land use planning (Fig. 5). According to the soil quality index, calculated for three crops, three ranges were distinguished and are shown on this Figure as 0-40, 40-60, 60100 values. Higher soil quality index values indicate better soil quality. The darkest colour represents the most fertile area in the field according to winter wheat, maize and sunflower, respectively (Fig. 5). The use of such maps is evident for the farmers, as these provide quantitative spatial information for the selection of optimal crops to be grown in the fields.

The land valuation system is in the focus of national interest and is supported by societies of growers, national administrative authorities of agriculture and informatics, and also by the European Union authorities.

\section{Summary}

An internet-based land valuation system is being developed to replace the scientifically obsolete Hungarian land valuation system, the so-called AK ("Gold Crown") ratings. The new system is supported by a GIS and it is unique in its capability of providing an up-to-date index of soil quality and land value. The geographical information is provided by national map databases on genetic soil maps and soil attributes at the scale of 1:10.000, combined with cadastral maps, digital terrain model, topographic map, orthophotos of aerial photographs and agronomic field records. The automated algorithms are easy to update, can be made legally binding and can provide a transparent system for land taxation, calculation of subsidies, appropriation. Given that detailed (1:10,000 or finer) soil map coverage will be completed for all lands of Hungary (at date only $60 \%$ of the croplands have soil maps), this way a multifunctional system will be available that promotes an optimum use of land resources.

The presented work was supported financially by the National Research and Development Programme (OM-4/015/2004 NKFP and GVOP (AKF) - 2004 - 3.1.1 grants). 
Key words: land value, soil quality index, GIS, genetic soil type map, cadastral unit

\section{References}

BIDLÓ, A. et al., 2003. Forest habitat classification in Hungary and its problems. In: Land Valuation and Land Use Information. (Eds.: GAÁL, Z., MÁTÉ, F. \& TÓTH, G.) (In Hungarian) 115-124. Veszprém University. Keszthely.

BirCSÁK, É. \& NÉMETH, T., 2002. Nitrate-N in the soil profiles of long-term field experiments. Agrokémia és Talajtan. 51. 139-146.

BurROUGH, P. A., 1987. Mapping and map analysis: new tools for land evaluation. Soil Use \& Management. 3. 20-25.

DÉR, F. et al., 2003. Habitat evaluation of grasslands. In: Land Valuation and Land Use Information. (Eds.: GAÁL, Z., MÁTÉ, F. \& TÓTH, G.) (In Hungarian) 125-130. Veszprém University. Keszthely.

Fórizs, J., MÁtÉ, F. \& Stefanovits, P., 1971. Soil bonitation - land valuation. (In Hungarian) MTA Agrártud. Oszt. Közlem. 30. (3) 359-378.

GAÁL, Z., MÁTÉ, F. \& TóTH, G. (Eds.), 2003. Land Valuation and Land Use Information. (In Hungarian) Veszprém University. Keszthely.

Lemmens, M. J. P. M. \& KURM, J., 2000. Integrating GIS with a Land Valuation Information System: some non-technical considerations for the Estonian case. In: Proc. UDMS 2000, 22 ${ }^{\text {nd }}$ Urban Data Management Symposium, Delft. (Ed.: FENDEL, E. M.) IX. 15-23.

MAGYAR, M. et al., 2002. Correlations among different P-test methods studied in a network of Hungarian P fertilization long-term field trials. Agrokémia és Talajtan. 51. $167-176$.

RossiteR, D. G., 1996. A theoretical framework for land evaluation. Geoderma. 72. $165-202$.

SzABOLCS, I., 1966. Methods of Large-scale Mapping of Soil Genetic Types. (In Hungarian) OMMI. Budapest.

VASS, J. et al., 2003. Information technology of D-e-Meter internet-based land bonitation system. In: Land Valuation and Land Use Information. (Eds.: GAÁL, Z., MÁTÉ, F. \& TóTH, G.) (In Hungarian) 57-77. Veszprém University. Keszthely.

VinCZEFFY, I., 1993. Pasture and Grassland Management. (In Hungarian) Mezögazda Kiadó. Budapest. 